\title{
Familiar Spaces: (National) Home in Contemporary Taiwanese Tourist Souvenirs
}

Adina Zemanek

\section{(2) OpenEdition \\ Journals}

Electronic version

URL: http://journals.openedition.org/chinaperspectives/7291

ISSN: 1996-4617

\section{Publisher}

Centre d'étude français sur la Chine contemporaine

\section{Printed version}

Date of publication: 1 June 2017

Number of pages: 7-17

ISSN: 2070-3449

Electronic reference

Adina Zemanek, «Familiar Spaces: (National) Home in Contemporary Taiwanese Tourist Souvenirs », China Perspectives [Online], 2017/2 | 2017, Online since 01 June 2017, connection on 28 October 2019. URL : http://journals.openedition.org/chinaperspectives/7291 


\title{
Familiar Spaces: (National)
}

\section{Home in Contemporary}

\section{Taiwanese Tourist Souvenirs}

\author{
ADINA ZEMANEK
}

\begin{abstract}
This paper discusses depictions of space in contemporary tourist souvenirs manufactured by private companies that explicitly undertake defining and promoting Taiwan for a local and international audience. They highlight "Taiwan" as the nation's name, associate it with the island's map as national territory, and fill this territory not only with iconic landmarks, but above all with ordinary, familiar spaces and sights. The latter are de-naturalised for the purpose of building national identity understood as a specifically Taiwanese way of life. As historical palimpsests, the depicted landscapes also construct a national heritage not based on a single, local tradition, but shaped by manifold native and external factors. This definition of Taiwan can be deemed a grassroots response to official undertakings in nation branding that frame the island as preserver of high, traditional Chinese culture and downplay politically sensitive local elements. Its non-antagonistic character may be a function of the medium (commercial popular culture), but may also reflect a new stage in the articulation of Taiwanese identity, based on the need to appeal to the entire national community, notwithstanding ethnic and political divides.
\end{abstract}

KEYWORDS: national identity, tourist souvenirs, postcards, iconic sites, everyday sights, national heritage.

\section{Introduction}

T he late 1980s and the 1990s in Taiwan ushered in a trend towards indigenisation, aimed at formulating a distinct national identity, a process still ongoing for several reasons, such as the island's international situation, its uneasy relationship with China, and a polarised political scene with intense electoral competition between parties that work towards different agendas. Many researchers ${ }^{(1)}$ emphasise the self-conscious and selfreflexive character of nation building in Taiwan as a post-Andersonian project, which borrows from existing theory and other countries' experiences in order to construct a common identity for Taiwan, where a national territory, a government, and a people are already present.

Much has been written about Taiwanese identity - indeed, current English-language scholarship on Taiwan seems concerned with little else. (2) However, it has not equally reflected all the manifold fields where the national project is now articulated. Studies to date have mainly focused on the political discourse, ${ }^{(3)}$ the academic discourse (especially history writing), ${ }^{(4)}$ Taiwanese journalism and literature, ${ }^{(5)}$ student and social movements, or ethnicity, ${ }^{(6)}$ and also include social surveys. ${ }^{(7)}$ My observations revealed a marked preoccupation with defining Taiwan in contemporary popular culture. This definition only partly overlaps with existing accounts of Taiwanese identity and is consistently present across various kinds of texts: comic books, tourist souvenirs, and recent films. Although increasingly diversified, ${ }^{(8)}$ research into Taiwanese identity in popular culture is concerned mainly with cinema. ${ }^{(9)}$ This paper will focus on present-day tourist souvenirs, which have not become a topic of academic inquiry as yet.
1. Mark Harrison, "How to Speak About Oneself:Theory and Identity in Taiwan," in Chris Berry, Nicola Liscutin, and Jonathan D. Mackintosh (eds), Cultural Studies and Cultural Industries in Northeast Asia: What a Difference a Region Makes, Hong Kong, Hong Kong University Press, 2009, p. 58; Daniel C. Lynch, "Taiwan's Self-Conscious Nation-Building Project," Asian Survey, Vol. 44, No. 4, 2004, pp. 513-514.

2. Jeremy E. Taylor, "Oujianghua: Disposing of and Re-appraising the Remnants of Chiang Kai-shek's Reign on Taiwan," Journal of Contemporary History, Vol. 45, No. 1, 2010, p. 183.

3. Bruce Jacobs, "'Taiwanization' in Taiwan's Politics," in John Makeham and A-chin Hsiau (eds), Cultural, Ethnic and Political Nationalism in Contemporary Taiwan: Bentuhua, New York and Houndmills, Palgrave Macmillan, 2005, pp. 17-54; Fu-chang Wang, "A Prolonged Exile: National Imagination of the KMT Regime in Postwar Taiwan," Oriens Extremus, Vol. 52, 2013, pp. 137-172.

4. Daniel C. Lynch, "Taiwan's Self-Conscious Nation-Building Project," art. cit:Fu-chang Wang "Why Bother About School Textbooks? An Analysis of the Origins of the Disputes Over Renshi Taiwan Textbooks in 1997," in John Makeham and A-chin Hsiau (eds), Cultural, Ethnic, and Political Nationalism..., op. cit., pp. 55-99.

5. A-chin Hsiau, Contemporary Taiwanese Cultural Nationalism, London and New York, Routledge, 2000; Huigui xianshi: Taiwan yijiuqiling niandai de zhanhou shidai yu wenhua zhengzhi bianqian (Return to reality: Political and cultural change in 1970s Taiwan and the postwar generation), Taipei, Institute of Sociology, Academia Sinica, 2010; Chonggou Taiwan: dangdai minzuzhuyi de wenhua zhengzhi (Reconstructing Taiwan: The cultural politics of contemporary nationalism), Taipei, Lianjing, 2012.

6. Fu-chang Wang, Dangdai Taiwan shehui de zuqun xiangxiang (Ethnic imagination in contemporary Taiwan), Taipei, Qunxue, 2003.

7. Shiau-chi Shen and Nai-teh Wu, "Ethnic and Civic Nationalisms: Two Roads to the Formation of a Taiwanese Nation," in Peter Chow (ed.), The "One China" Dilemma, New York, Palgrave Macmillan, 2008, pp. 117-143.

8. The following publications concern baseball, national cuisine, political cartoons, and the daily press: Andrew D. Morris, Colonial Project, National Game: A History of Baseball in Taiwan, Berkeley, Los Angeles, and London, University of California Press, 2011; Chen Yuzhen, "Shiwu xiaofei zhong de guojia, jieji yu wenhua zhanyan: rizhi yu zhanhou chuqi de 'Taiwan cai'," (Nation, class and cultural presentation: "Taiwanese cuisine" during the Japanese colonial era and early post-war Taiwan), Taiwanshi yanjiu, Vol. 15, No. 3, 2008, pp. 139-186; Ann Heylen, "Reading History and Political IIlustration in Taiwan Popular Culture," Oriental Archive,Vol. 81, 2013, pp. 1-25; Ye Chunjiao, Guozu rentong de zhuanzhe: Taiwan minzhong yu jingying de gushi (National identity in transition: elite and mass narratives), Taipei, Daoxiang, 2010.

9. June Yip, Envisioning Taiwan. Fiction, Cinema and the Nation in the Cultural Imaginary, Durham and London, Duke University Press, 2004; Guo-Juin Hong, Taiwan Cinema: A Contested Nation on Screen, New York, Palgrave Macmillan, 2011. 
In a recent article, Gary Rawnsley shows how the lack of a consistent public diplomacy strategy and of coordination between government institutions in charge of Taiwan's soft power has caused failure in proposing coherent messages with actual international appeal. Moreover, state-conducted public diplomacy is ideologically marked - its main trends are formulated according to the political agenda of the dominant party. As Ma Ying-jeou's administration was more conciliatory towards the PRC than Chen Shuibian's, its soft power activities steered away from political issues such as democracy to emphasise Taiwan's role as "preserver of traditional Chinese culture," (10) thus pushing the island into China's shade and reducing its international visibility. The Taiwan Academy, a project proposed by Ma Yingjeou in 2008 and implemented since 2011 by the Ministry of Culture, positions Taiwan as "the major Chinese cultural center where Confucianism, Buddhism, Zen [sic!], literature, architecture, arts and crafts, and traditional customs are promoted and preserved more completely as compared to the many regions influenced by Chinese culture." (11) Promotional materials commissioned by the Ministry of Foreign Affairs, such as a diary pad designed by the government-operated Taiwan Panorama magazine and distributed in 2015 by Taipei Economic and Cultural Offices, showcase the island's Chinese connections. The diary is bound in red brocade of the type used for mounting traditional paintings and calligraphy; it features papercuts and artefacts from the National Palace Museum. Though also represented, specifically Taiwanese accents are downplayed: Dutch and Spanish presence on the island is explicitly mentioned but the Japanese rule is not; photographs from museums of Taiwanese history and literature focus on architecture and generic "Asian poetry." The nation-branding slogan "Taiwan The Heart of Asia" launched by the Taiwan Tourism Bureau in 2011 displays an apparently different approach by placing Taiwan at the centre. However, most graphic elements in the accompanying logo highlight the island's Chinese heritage: a building resembling the Sun Yat-sen Memorial Hall, red lanterns, a teapot, steamed buns and chopsticks, or the Taipei 101 building, the design of which incorporates auspicious Chinese symbols. The overall message these initiatives convey internationally is thus politically safe and at best undecided.

State institutions are but one of many sources that articulate Taiwanese identity, and the China-centred or ambiguous message discussed above is but part of the many images of Taiwan that circulate, intersect, and compete in the island's public discourse. The present paper will show how texts of popular culture (tourist souvenirs) outside the realms of state institutions and official discourse construct a highly coherent image of Taiwan for both a domestic and a foreign audience, incorporating certain motifs from stateled nation branding projects but firmly anchored in the local. This process is self-conscious in that the producers of these texts explicitly undertake the task of defining Taiwan, and self-reflexive in that this definition involves de-naturalisation and resembles an exercise in applying well-known concepts from an international academic discourse on nationhood. It aims to make Taiwan visible as an individualised entity by naming the nation, emphatically delineating its territory, and filling it with a multitude of iconic landmarks, everyday sights, and familiar objects. These landscapes and objects play several roles: they depict Taiwan as a familiar, homely space, and embody both a specific Taiwanese way of life and a collective memory. Thus the analysed texts revisit the concept of "community of fate" (mingyun gongtongti 命運共同體) (12) that emerged in the late 1980s and became popular in the early 1990s, when Lee Teng-hui advocated it in his project of Taiwanisation. ${ }^{(13)}$ Although this concept was centred around ethnicity, I argue that its most recent evolution moves away from that initial focus and brings history, geography, and everyday life to the fore as the basis for creating a sense of community and solidarity.

\section{Research material}

The role of tourism, sites, and sights in conveying nationhood has been elaborated by many scholars; ${ }^{(14)}$ tourist souvenirs record iconic representations of space that contribute to place branding and nation building. ${ }^{(15)}$ This project is based on fieldwork conducted in bookstores and souvenir, stationery, and other shops in Taipei and the New Taipei City area. ${ }^{(16)}$ Alongside souvenirs depicting motifs that Edensor ${ }^{(17)}$ terms a "national landscape ideology," i.e., natural or man-made iconic sites already imbued with national significance, cityscapes representing (national) modernity, or aboriginal folk culture, which are used in many countries or have been used in Taiwan since Japanese colonial times, ${ }^{(18)}$ many other objects were available that aimed exclusively at branding the nation (by picturing national symbols, such as the flag) or that presented everyday life at home or in the city, images of the past before or after the Second World War, or Taiwan's geography and biodiversity. It was the less conventional image of Taiwan constructed by this latter type of souvenirs that aroused my interest, and the present paper focuses on one of its aspects - depictions of space in present-day Taiwan. Some of these artefacts stylistically resemble the "Taiwan - The Heart of Asia" logo; others are different in style, but exploit certain themes of the official nation-branding project. However, the voices that formulate this national project do not belong to the official discourse, but are diverse and come from the grassroots - these objects (postcards, stickers, refrigerator magnets, bookmarks, glass coasters, and so on) are produced by private publishing houses or companies specialising in tourist souvenirs and stationery. ${ }^{(19)}$ The size and degree of availability of their product range vary Miin Design and Milu Design have a large and diversified offering (postcards and others), readily available at bookstores such as Eslite; Renren Publishing Co. Ltd. specialises in postcard series, also distributed by many bookstores; the Taiwan Railway Company offers souvenirs other than postcards, available in shops at tourist sites; Qingtian Paper Gifts Ltd.'s sticker sets were on sale

10. Gary Rawnsley, "Taiwan's Soft Power and Public Diplomacy," Journal of Current Chinese Affairs, Vol. 43, No. 3, 2014, p. 170.

11. See the "About Us" section of the Taiwan Academy website http://english.moc.gov.tw/ article/index.php?sn=2721 (accessed on 15 October 2016).

12. For a definition of this concept, see Fu-chang Wang, Dangdai Taiwan shehui de zuqun xiangxiang (Ethnic imagination in contemporary Taiwan), op. cit., p. 81.

13. Bi-yu Chang, "From Taiwanisation to De-sinification: Culture Construction in Taiwan Since the 1990s," China Perspectives, Vol. 56, 2004, pp. 2, 13; A-chin Hsiau, Contemporary Taiwanese Cultural Nationalism, op. cit., p. 104

14. See Kalyan Bhandari, Tourism and National Identity: Heritage and Nationhood in Scotland, Channel View Publications, Bristol, Buffalo \& Toronto, 2014; Tim Edensor, National Identity, Popular Culture and Everyday Life, Oxford and New York, Berg, 2002, pp. 39-50; Shelley Hornstein, Losing Site: Architecture, Memory and Place, Farnham and Burlington, Ashgate, 2011, pp. 58-59.

15. See Shelley Hornstein's discussion of postcards in Losing Site: Architecture, Memory and Place, op. cit., p. 52.

16. However, the relevance of my sample is not restricted to this area - although most souvenir producers are based in Taipei, their products were available all over the island, online, and at chain bookstores (such as Eslite). Moreover, as indicated further, the depicted sites and sights are from various places in Taiwan or recurrent all over the island.

17. Tim Edensor, National Identity, Popular Culture and Everyday Life, op. cit., p. 40.

18. Joseph R. Allen, Taipei: City of Displacements, Seattle, University of Washington Press, 2012, pp. 33-35 and 41-43; Paul D. Barclay, "Peddling Postcards and Selling Empire: Image-Making in Taiwan Under Japanese Colonial Rule," Japanese Studies, Vol. 30, No. 1, 2010, pp. 81-110.

19. The only exceptions in my research sample are a postcard printed by the Taipei Fine Arts Museum, a limited edition EasyCard and the station magnet. 
at stationery shops and supermarkets; Frogfree is a small company that sells online and at a Taipei coffee shop. Most manufacturers advertise themselves as representatives of local creativity who formulate and promote an image of their homeland. (20) Apart from assuming the existence of a Taiwanese national community ("we") and asserting emotional attachment to it, some of them take political stances that ran counter to current official views at the time of my research (February-October 2014), and associate themselves with social activism - Frogfree advocates Taiwan's independence and protests against nuclear energy. (21) The overall number of such products on the market (22) indicated that what seemed to constitute a grassroots exercise in appropriating and developing the state-initiated nation-branding project had become a large-scale phenomenon.

Some of the analysed souvenirs bear inscriptions in both English and Chinese. Others are only inscribed in Chinese (mostly standard Mandarin, sometimes Hoklo in Chinese characters) and depict elements of local culture not readily available to foreigners (such as China Strong canvas shoes, or campus folk singer Yang Zujun). Many souvenirs in my sample were sold off the beaten tourist track (23) (at the Taipei Fine Arts Museum, coffee shops, the Taiouan-e-diam near Xinsheng South Road, or a 1920s-themed bookstore on Dihua Street) and even beyond travel destinations (Carrefour markets outside the city centre). Therefore, such objects may be consumed both as tourist items and as collectibles, and the image of Taiwan they construct is addressed to both a foreign and a local audience. (24)

\section{Theoretical and methodological framework}

This paper is based on Benedict Anderson, Michael Billig, and Tim Edensor's constructivist approach to the nation. The latter speak of national identity as a "form of life, which is daily lived in the world of nation-states," a national "we" imagined on the basis of elements that include the nation's name, its territory, and history (discussed in this paper), (25) "a common sense that this is how things are and this is how we do things." (26) A-chin Hsiau also connects national identity to a specific way of life and applies it to Taiwan within the framework of cultural nationalism: "Cultural nationalists believe that national identity is mainly a matter of consciousness which rests on internalising a particular way of life as a result of unique national history and geography, rather than on simply participating in contemporary sociopolitical processes under the rule of a state." (27) In tune with his theoretical framework, Hsiau focuses on intellectual elites (literary and academic circles). While drawing on his understanding of national identity, my study turns towards mass-produced consumer products and a definition of Taiwan purposefully designed as non-elite.

Theorists of everyday nationhood and banal nationalism such as Edensor, Billig, Fox, and Miller-Idriss, argue that not only macro-structural factors are involved in nation-building, that nationhood is not only called upon during national crises or spectacular displays, and is not only the product of cultural elites. National identity is embedded into the daily life of ordinary people, constantly "flagged" by banal cues that interpellate them as national subjects, ${ }^{(28)}$ experienced in everyday routines, familiar landscapes, and among well-known objects, which create a sense of national belonging, ${ }^{(29)}$ and is performed through everyday discursive practices, choices, and decisions, ritual enactments of national symbols, and consumption habits. ${ }^{(30)}$ My study will not focus on people and cultural practices, but on representations of iconic and mundane landscapes in texts of popular culture, an approach also adopted by Edensor. ${ }^{\left({ }^{11}\right)}$ However, it will show these scholars' theoretical framework at work in a different context. They speak of established nations and of the ways in which an already internalised, naturalised nationhood and national identity are reproduced and maintained in the everyday. This takes place unreflexively: Billig uses the metaphor of "the flag hanging unnoticed on the public building," (32) and Fox and Miller-Idriss mention that nationhood "operates at the level of unselfconscious disposition." (33) I argue that since Taiwan's nation-building is still in progress, my research material takes familiar, ordinary sights that usually go unnoticed and displaces them from their actual-life context to de-naturalise and mobilise them in a selfconscious effort at defining a specific Taiwanese way of life. This strategy effaces the ongoing character of national identity construction and presents Taiwaneseness not as an ever-elusive "object in suspension," a "future possibility of a singular, naturalised, unifying identity" to be sought for and established through "an active discursive process," (34) but as already constituted and easily available in a daily life environment.

In her account of architecture and memory, Shelley Hornstein points out that visual images of particular sites do not simply record physical objects and their spatial environment, but are the results of curatorial acts that select and arrange specific views, endowing them with cultural meaning. Moreover, images of places also involve memories - they either act as aidemémoire for persons who have visited them by recalling experiences lived at those locations, or help construct mental images of places never visited, subsequently preserved in memory. ${ }^{(35)}$ Hornstein also discusses picture postcards that build Israel's image as an emerging nation. ${ }^{(36)}$ Postcards are usually available for on-site purchase at visited locations and brand their image while transporting it elsewhere, often abroad. They are curated, iconic representations of a certain place in time, and tell stories of the brand they contribute to build. The branding strategy they employ consists of inciting desire for the places they depict; they also "address the collective anxieties and desires of a nation." (37) This paper assumes similar roles for the analysed

20. See the company presentation sections of Miin Design (miingift.so-buy.com), Milu Design (miludesign.com), or Taiwan Railway Company (Taiwan tiedao gushiguan, tr.net.tw, accessed on 14 March 2015).

21. See http://www.frogfree.com/shop.frogfree.com/ (Accessed on 24 July 2015).

22. The years of issue provided on some of the items in my sample are 2012, 2013, and 2014.

23. For the most popular travel destinations, see Tourism Bureau, Ministry of Transportation \& Communications, R.O.C., 2014 Annual Survey Report on Visitors Expenditure and Trends in Taiwan, pp. viii-ix, http://admin.taiwan.net.tw/statistics/market_en.aspx?no=16 (Accessed on 15 October 2016).

24. The former seems to be a generalised global public. Although for linguistic reasons PRC tourists might constitute a target group, shop assistants I interviewed emphasised their interest in souvenirs related to Chiang Kai-shek and martial law era anti-communist propaganda rather than the products analysed here.

25. Michael Billig, Banal Nationalism, London, Thousand Oaks and New Delhi, Sage, 1995, pp. 69, 7078.

26. Tim Edensor, National Identity, Popular Culture and Everyday Life, op. cit., p. 19.

27. A-chin Hsiau, Huigui xianshi... (Return to reality...), op. cit., p. 14.

28. Michael Billig, Banal Nationalism, op. cit.

29. Tim Edensor, National Identity, Popular Culture and Everyday Life, op. cit.

30. Jon E. Fox and Cynthia Miller-Idriss, "Everyday Nationhood," Ethnicities, Vol. 8, No. 4, 2008, pp. 536-563.

31. Tim Edensor, National Identity, Popular Culture and Everyday Life, op. cit., pp. 139-170.

32. Michael Billig, Banal Nationalism, op. cit., p. 8.

33. Jon E. Fox and Cynthia Miller-Idriss, "Everyday Nationhood," art. cit., p. 539

34. Mark Harrison, "How to Speak About Oneself: Theory and Identity in Taiwan," art. cit., p. 58.

35. Shelley Hornstein, Losing Site: Architecture, Memory and Place, op. cit., pp. 11-13.

36. Ibid., pp. 50-62.

37. Douglas Holt, quoted in Shelley Hornstein, Losing Site: Architecture, Memory and Place, op. cit., p. 52. 
tourist souvenirs: in response to present-day needs and anxieties, they construct various sites as objects of desire, tell stories of Taiwan, and build an image of the island as national homeland. They brand Taiwan internationally, and thus work as a form of public diplomacy within the framework established by Rawnsley. ${ }^{(38)}$ Hornstein's project takes into consideration both the visual images on picture postcards and the senders' textual messages written on the back side. ${ }^{(39)}$ Though I acknowledge the pertinence of this approach, I only discuss the chosen souvenirs as texts in themselves, outside the context of reception, postcard exchange, and communication practices that the tourist experience implies.

As postcards and other souvenirs are part of the tourism industry, I shall also quote John Urry and Jonas Larsen's discussion of tourism, nation-building, and commodification of heritage. ${ }^{(40)}$ I consider my research material to be both based on an already established tourist gaze as a culturally and socially patterned vision inherent in the experience of modern tourism ${ }^{(41)}$ and to produce a certain kind of gaze ${ }^{(42)}$ upon Taiwan that articulates its local specificity.

My analysis touches upon the concept of nation branding, defined by Melissa Aronczyk as "the creation and communication of national identity using tools, techniques, and expertise from the world of corporate brand management" (43) in order to increase the nation-state's global competitiveness in attracting tourists or foreign investment. Aronczyk's critical approach exposes the elitism of such projects, initiated by governments, designed by a "transnational promotional class," (44) implemented by local NGOs and private businesses, but which downplay the role of civil society and individual actors, ignoring their creative potential. ${ }^{(45)}$ However, Aronczyk's and similar studies ${ }^{(46)}$ are centred upon these very elitist practices, while my paper proposes a complementary perspective. It considers nation branding strategies carried out outside the state but which engage in a dialogue with state-led projects whose elements they appropriate and develop into images of Taiwan that are refocused, endowed with coherence despite their manifold sources, and echo significant local discourses.

Aronczyk and Kaneva ${ }^{(47)}$ approach nation branding both as a field where various actors vie for scarce resources, and as a discourse that concerns the process and is embodied in texts - national images, such as advertisements or logos. Billig (48) and Fox and Miller-Idriss ${ }^{(49)}$ speak of nationhood as produced and reproduced by means of discursive acts. Harrison also refers to Taiwanese identity as a form of social knowledge under incessant construction. ${ }^{(50)}$ Since I explore the outcome of what I perceive to be grassroots undertakings in nation branding, the strategies employed to construct Taiwan as object of knowledge, and the way this image of Taiwan is grounded in existing discourses, my paper also embraces a discourse analytical approach.

Discourses construct social reality and give meaning to social interaction; their effects are to be determined through systematic investigation of texts (discursive units) that are interconnected, may take various forms (written, spoken, graphic, material, or other $\left.{ }^{(51)}\right)$, and simultaneously make meaning in several semiotic modes (visual, linguistic, layout, etc.). ${ }^{(52)}$ Discourse is "a coherent pattern of statements across a range of archives and sites"; ${ }^{\prime 53}$ its intertextual nature and the presence of coherent discourse formations ${ }^{(54)}$ in many diverse materials justifies the choice of different kinds of texts for analysis (postcards and other tourist souvenirs). Discourses are processes; their analysis examines how objects of knowledge are produced and maintained in a larger context, influenced by dynamic balances of hegemony between social actors at different historical moments. ${ }^{(55)}$ Transformations in the socio-political environment of communication, situations of insta- bility, and renegotiation of power require re-assessment of social relations, the audience, communicative needs, available semiotic resources, and their potential effectiveness. ${ }^{(56)}$

My study perceives the analysed texts as representing a stage in the process of knowledge production and communication regarding "Taiwaneseness." It aims at revealing change in a broader environment; it comments on actors that formulate Taiwan's image, incentives for change, new contributions, and borrowings from earlier discourses. However, the main argument of my article is not centred on actors themselves, their motivations and actions, but on the Taiwan-related message that they convey. The topics discussed below constitute dimensions of this message and are based on research material consisting of 36 items. They are part of a larger corpus of tourist souvenirs selected by employing theoretical sampling, i.e., according to their relevance for the less conventional approach to Taiwan mentioned at the beginning of the previous section, and for the categories that emerged during their analysis. ${ }^{(57)}$

\section{Naming the nation and defining its territory}

Anderson ${ }^{(58)}$ points out that the nation is imagined across space as a community of people who inhabit the same territory. Among the various instances of "flagging" it in everyday life, Billig mentions the nation's name, the distinctive label that confirms that a national community exists and distinguishes it from other similar groups in a world of nations. ${ }^{(59)} \mathrm{He}$ also speaks of imagining the homeland as a geographical totality contained within national borders, which unites actually experienced localities. Edensor

38. Gary Rawnsley, "Taiwan's Soft Power and Public Diplomacy," art. cit.

39. Shelley Hornstein, Losing Site: Architecture, Memory and Place, op. cit., p. 60.

40. John Urry and Jonas Larsen, The Tourist Gaze 3.0, London, Thousand Oaks, New Delhi \& Singapore, Sage, 2011.

41. Ibid., pp. 2-3

42. Ibid., p. 119.

43. Melissa Aronczyk, Branding the Nation: The Global Business of National Identity, Oxford and New York, Oxford University Press, 2013, p. 16.

44. Ibid., p. 39

45. Ibid., p. 78-79; "How to Do Things with Brands: Uses of National Identity," Canadian Journal of Communication, Vol. 34, 2009, p. 293.

46. Nadia Kaneva, "Who Can Play This Game? The Rise of Nation Branding in Bulgaria, 2001-2005," in Nadia Kaneva (ed.), Branding Post-Communist Nations: Marketizing National Identities in the "New" Europe, New York and London, Routledge, 2012, pp. 99-123.

47. Ibid.

48. Michael Billig, Banal Nationalism, op. cit., p. 93.

49. Jon E. Fox and Cynthia Miller-Idriss, "Everyday Nationhood," art. cit., p. 538

50. Mark Harrison, "How to Speak about Oneself," art. cit., p. 57.

51. Nelson Phillips and Cynthia Hardy, Discourse Analysis. Investigating Processes of Social Construction, Thousand Oaks, London \& New Delhi, Sage, 2002, pp. 2-4.

52. Gunther Kress, "What is Mode?", in Carey Jewitt (ed.), The Routledge Handbook of Multimodal Analysis, London and New York, Routledge, pp. 54.

53. Nicholas Green, The Spectacle of Nature: Landscape and Bourgeois Nature in Nineteenth-Century France, Manchester, Manchester University Press, 1990, p. 3.

54. Michel Foucault, The Archaeology of Knowledge and the Discourse on Language, transl. by A.M. Sheridan Smith, New York, Pantheon Books, 1972.

55. Nelson Phillips and Cynthia Hardy, Discourse Analysis: Investigating Processes of Social Construction, op. cit., pp. 3-6.

56. Gunther Kress, Multimodality. A Social Semiotic Approach to Contemporary Communication, London and New York, Routledge, 2010, pp. 45-46, 49-50.

57. See Kathy Charmaz, Constructing Grounded Theory: A Practical Guide Through Qualitative Analysis, London, Thousand Oaks, New Delhi, Sage, 2006, pp. 96-115.

58. Benedict Anderson, Imagined Communities, London and New York, Verso, 1991, pp. 6-7.

59. Michael Billig, Banal Nationalism, op. cit., p. 73. 


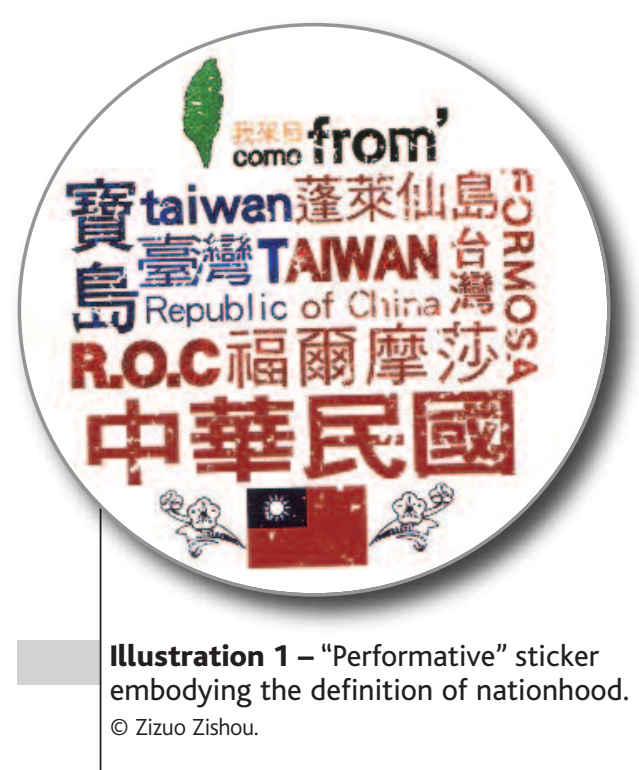

shows that the nation is constructed as a bounded space; the borders act as a performative statement of that nation's common-sense existence and enclose a particular culture while delineating it from others. ${ }^{(60)}$

Most analysed items (29 out of 36) highlight the island's name as that of the nation. The word "Taiwan" in Latin letters and/or Chinese characters is conspicuously and often repeatedly placed on the front or back side. A series of folding postcards by Miin Design even engage the purchaser in an interactive game of making Taiwan visible - they provide stickers with a round logo bearing Taiwan's name in English and Chinese to be used for closing the postcard before sending, the way shop-assistants seal shopping bags using stickers or sticking tape with the shop name or logo. By joining in this game, the purchaser is placed within Taiwan and entrusted with the task of branding Taiwan internationally by sending the thus branded postcard abroad. Taiwan's name is not employed as simply that of a geographical locality, but is part of a nation-building project designed with a universal perspective - Taiwan is constructed as part of an international world of nations, a global political order. The name is often accompanied by the national flag, ${ }^{(61)}$ this "conventional symbol of particularity," which due to its conventional character is at the same time a "symbol of the universality of nationhood." (62) Thus the state is cut off from any claims to the mainland and identified with the geographical location called "Taiwan." On a series of sticker sets by Qingtian Paper Gifts Ltd. presenting tourist attractions and distinguishing features of Taiwan, this idea is further hammered home by graphic representations of the flag placed within the name, inside the "mouth" component in the character tai 台 from Taiwan 台灣. In most cases, it is not the state's official name (the Republic of China or ROC) that cooccurs with the flag, but "Taiwan," which removes any connection with China. In the same sticker series, Taiwan's claim to international recognition as a nation is also suggested by images of the Taiwanese passport, whose overall look follows the official design, except that the word - "Taiwan" - is printed in considerably larger size than the name - "Republic of China."

Taiwan's name also frequently co-occurs with the island's map. The map is usually only given as a contour, which reinforces the idea of a self-contained and bounded geographical entity above regional divisions. Name and map are visually displayed as organically interrelated - the phrases Taiwan zui meili de jiaoluo 台灣最美麗的角落 and "Most beautiful corner in Taiwan" (63) form the island's overall shape in a series of Frogfree postcards.
One postcard by Renren Publishing Co. Ltd. is exclusively dedicated to this geographical totality and its name. It consists of as many as 29 stickers with Taiwan's map in various sizes and colours. The postcard imprints Taiwan's shape in the viewer's sight both with and without the stickers: even after detaching them from the postcard, their trace still remains as a contour. This postcard also contains 19 other stickers with the island's name, either placed over the map or separately.

The national territory, the nation's name, the state, and the people are shown as bound in unity on one sticker that works as a quintessential illustration of the basic definition of nationhood. (64) The sticker displays various names that designate Taiwan, including the official state name and its English acronym (Taiwan, Formosa, Republic of China, R.O.C., Taiwan 台灣, Baodao 寶島, Penglai Xiandao 蓬萊仙島, Fuermosha 福爾摩沙, Zhonghua Minguo 中華民國) in dark red and blue, arranged in the rectangular shape of the national flag, also given below in its regular form. On top of this image is an utterance that constructs a national community identified with the national territory in the English version: "I come from...," where the island's map replaces the letter "I." The sticker thus functions as a performative utterance: it positions its user as a national subject who makes a national statement, and constructs Taiwan as a national home. The homely character of this space is highlighted by the words Penglai Xiandao and Baodao, which establish an affective bond between the utterer ("I") and Taiwan pictured as a heaven by playing upon the mythical connotations of the name "Penglai." The use of "Formosa," on the other hand, is a political statement of local (as opposed to Chinese) consciousness.

The island's contour is not always given only as such, but sometimes is also depicted as an enclosure suggesting national unity. In one case (a

60. Tim Edensor, National Identity, Popular Culture and Everyday Life, op. cit., p. 37.

61. My research material promotes "Taiwan" as the nations name more conspicuously than the official state name. However, it displays the official R.O.C. flag instead of taking over the alternative designs proposed by pro-independence circles, and thus refrains from openly challenging the official status quo. This lack of consistency in constructing the nation as separate from the state is part of the overall non-antagonistic character of the nationalistic project in my research material and is discussed in the final part of this article.

62. Michael Billig, Banal Nationalism, op. cit., p. 85.

63. All inscriptions quoted throughout this paper are in the language(s) in which they occur in my research material.

64. "In essentials, the theory of nationhood stipulates that a people, place and state should be bound in unity" (Michael Billig, Banal Nationalism, op. cit., p. 77). 


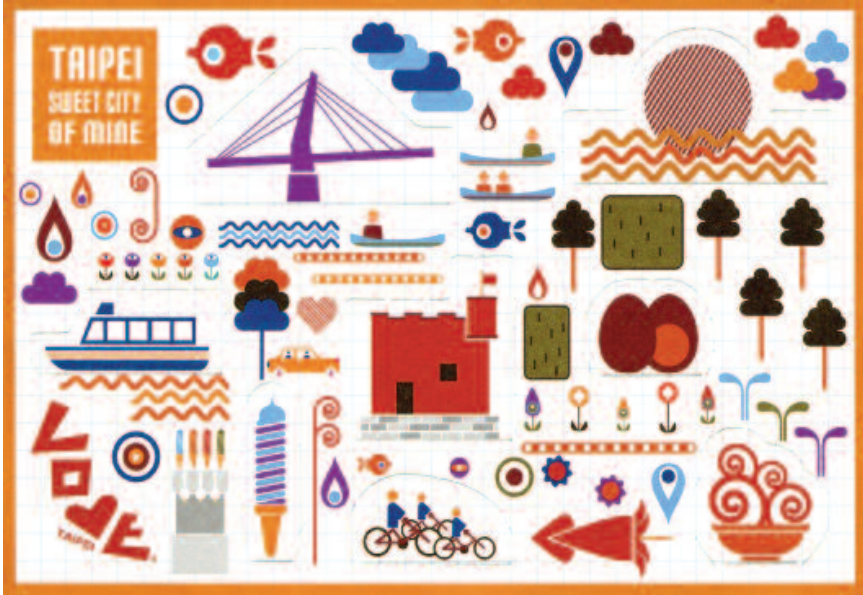

Illustration 3 - Turning sites into signs.

Postcard. ๑ Milu Design.

sticker from a set by Qingtian Paper Gifts Ltd.) it is drawn as a frame that sets off national symbols in a manner and style reminiscent of the "Heart of Asia" logo. However, the heart shape is replaced by Taiwan's map, and the enclosed symbols are both more numerous and more mundane. The plum blossom (Taiwan's national flower) and tea, which overlap with the official logo, are accompanied by other brand national products - bananas, pineapple, pineapple cakes, deep-fried chicken, and bubble tea. On two Frogfree postcards from different series, Taiwan's map with marked administrative divisions works as a showcase for an island-wide tour - each postcard displays on the face side a view from a certain locality, pinpointed on the map placed on the postcard's back side. Such depictions are reminiscent of the panoramic, bird's-eye-view Japanese colonial maps from the 1930s, which show the island's natural beauty and its modern progress, ${ }^{(65)}$ or maps from the late 1940s, the 1960s, and 1970s, which reflect the Nationalist Party (Kuomintang, KMT) government's promotion of tourism. Apart from the island itself, these maps would include Japan with its other colonies, Korea and Manchukuo, and mainland China's coast respectively. The images constructed in my research material also recall the round-the-island trips depicted in two films, Bai Ke's Descendants of the Yellow Emperor (1956) and Li Xing's Brother Wang and Brother Liu Tour Taiwan (1958), (66) where travelling across the island functions as a pretext for introducing a (Han) Chinese version of nationalism. On the contemporary Frogfree postcards, however, Taiwan is depicted separately, without any links to territories other than the archipelagos administered by the ROC; the only space of reference for nationwide travel is that delineated by the island's borders.

\section{Iconic sites, mobility across space and quotidian landscapes}

The role of travel to key natural and cultural sites in producing a sense of nationhood is discussed by Urry and Larsen, ${ }^{(67)}$ who trace the origins of this practice to 1851, when the Great Exhibition took place at London's Crystal Palace, followed by similar grand-scale tourist events in other countries during the next decades. The mid-nineteenth century also marked the beginning of travelling to major scenic spots, pieces of architecture, exhibitions, and other sites that embody or testify to national cultural achievements. My research material also proposes such established kinds of travel destinations: Mount Ali, the Taroko Gorge, the Queen's Head at Yeliu Geopark, the Tainan Confucius Temple, Taipei's Grand Hotel and Taipei 101, among others. What aroused my interest was not the presence of these tourist spots in itself, but the form in which they occur, discussed below.

According to Urry and Larsen, "the [tourist] gaze is constructed through signs, and tourism involves the collection of signs," of natural landscapes and unique artefacts that act as signifiers of pre-established notions about an essentialised national or regional character. ${ }^{(68)}$ Edensor ${ }^{(69)}$ also mentions ideologically and emotionally charged natural scenery and man-made iconic, emblematic sites that act as synecdoches for the entire nation. Alongside postcards specifically celebrating Taiwan's natural beauty and a general urban modernity in photographs thereof (not taken into consideration for this project), I found that another frequent presence on the market were postcards and sticker sets that collectively represent natural or manmade scenery from various localities around Taiwan or in the Taipei area through drawings instead of photographs. These are sometimes highly stylised, composed of a few simple elements that highlight characteristic traits, and accompanied by captions that identify and locate the objects thus pictured. The Twin-Heart Fish Trap in Qimei (Penghu) is shown as two blue interconnected boomerang-like shapes with the two characters for "Penghu" inside; the sunset at Danshui is depicted as a circle above three wavy lines, with the caption "Tamsui Sunset" (Danshui xiyang 淡水夕陽) on the back of the postcard; Fort San Domingo (identified as such on the reverse) is a red square with a crenelated top line, a small rectangle for the turret, and two black shapes for a door and window. Moreover, the same objects are repeatedly depicted in identical or very similar forms on different items coming from the same or different manufacturers (Milu Design and Qingtian Paper Cifts Ltd.). The graphic simplification and the reiteration of similar patterns establish a visual convention that induces a particular way of viewing places and marks them as brand logos for various cities or areas in Taiwan. This visual strategy turns actual scenery into signs and emphasises their iconicity, thus producing them as objects of a tourist gaze in search of typical, national sites (this latter fact is reinforced by the presence of Taiwan's name and national flag on top of the sticker sets). In addition, this strategy conforms to the design of the Tourism Bureau's heart-shaped logo, which uses the same colourful, simplified, and lightweight style and very similar patterns for buildings.

However, not all the tourist sites displayed on the imaginary travel map of Taiwan in my research material are equally conventional in character. Except for world-famous sites that would indeed list high in rankings of "mustvisit" places, there are also numerous objects that do not seem too susceptible of attracting crowds of tourists - the Lanyang Museum in Toucheng (Yilan County), the Longteng Bridge in Sanyi Township (Miaoli County), the jiantan MRT station in Taipei, the steel bridge over Dajia River on the Hou-Feng Bikeway in Taizhong's Fengyuan District, Taizhong Park, or the EcoARK pavilion of the 2010 Taipei Flora Expo. Some of them (such as the Longteng Bridge, the Dajia River Bridge, and Taizhong Park) are listed as cultural heritage assets or historical sites, representative of local tourist attractions; others, however, were only recently built (the Jiantan Station in 1997, and the EcoARK pavilion in 2010). Their presence in my research material could be explained by a need to increase the number of sites on Tai-

65. Joseph R. Allen, Taipei: City of Displacements, Seattle, University of Washington Press, 2012, p. 37.

66. Guo-Juin Hong, Taiwan Cinema: A Contested Nation on Screen, New York, Palgrave Macmillan, Pp. 43-52.

67. John Urry and Jonas Larsen, The Tourist Gaze 3.0, op. cit., p. 147.

68. Ibid., pp. 4-5, 15-16.

69. Tim Edensor, National Identity, Popular Culture and Everyday Life, op. cit., pp. 39-40 and 45-46 
wan's national tourist map, to emphasise the richness and diversity of Taiwan's national culture, and to increase the visibility of lesser localities by constructing them as attractive tourist destinations.

My research material features not only iconic sites from different locations over the island, but also objects related to the railways, which bind these locations together and make them accessible within an island-wide transportation network. The railways are a recurrent motif not only in my entire research corpus, ${ }^{(70)}$ but also in other texts of Taiwanese popular culture, such as films released during various periods: the already mentioned Descendants of the Yellow Emperor (1956), Liang Zhefu's The Last Train from Kaohsiung (1963) and The Early Train from Taipei (1964), and Hou Hsiao-hsien's Dust in the Wind (1986). As Hong points out, (71) trains in these cinematic works can be read as emblems of modernity, economic and social change, geographic movement, and movement in time. Apart from that, the railway system can also be said to aggregate separate localities into a national spatial imaginary, and to give rise to a sense of regularity and simultaneity across the "homogeneous, empty time" mentioned by Anderson as a constitutive feature of nationhood. ${ }^{(72)}$ My research material depicts railway stations (Xinzhu and Sandiaoling - in a sticker set issued by Qingtian Paper Gifts Ltd. and on a refrigerator magnet authorised by the Taiwan Railways Administration), Pingxi Line railway tracks on a photograph postcard by Renren Publishing Co. Ltd., and a station name plate, of the kind present everywhere across Taiwan, reproduced as a refrigerator magnet (Taiwan Railway Company). The standardised look of such plates emphasises nationwide uniformity; they place the current station between the previous and the next one while also stating the exact distances that separate them (the station featured on the magnet is Songshan, which comes $3.5 \mathrm{~km}$ after Nangang and $6.4 \mathrm{~km}$ before Taipei Main Station), thus picturing them as nodes within a larger network.

Railway stations and station name plates are not popular tourist sights (except among fans of railway culture $\left.{ }^{(73)}\right)$, but are part of the banal landscapes of everyday life. Such mundane, quotidian sights are ubiquitous in my research material. According to Urry and Larsen, ${ }^{(74)}$ the tourist gaze is based on contrast between its object and the observer's everyday living and working environment, on a search for difference, for the extraordinary, the unfamiliar in other times and places. It is also characterised by an incessant anticipation of things new and different, which causes a readiness to accept anything as a potential attraction, as long as it is presented as such. Urry and Larsen also mention the anti-auratic and anti-hierarchical nature of postmodernism, and a trend for local vernacular styles and unfamiliar aspects of social life hitherto not perceived as such. ${ }^{(75)}$ Edensor, on the other hand, considers national identity to be played out in familiar, everyday spaces and objects, habitual performances, and shared representations, which provide a reassuring sense of stability and groundedness and define the specific way of life of a certain national community. This shared sense of "how things are" and "how we do things" (76) is usually unreflexive, and becomes conscious only when these familiar routines are deemed to be threatened, or certain factors (such as travelling abroad) upset their continuity. The designers of the texts I analyse employ a strategy that consists of de-naturalising such everyday spaces, objects, habits, experiences, and representations in a selfconscious effort to define Taiwan. This de-familiarisation of the familiar is legitimised and made readily acceptable by placing it within the framework of tourism, in view of the expectations that the tourist gaze implies.

In terms of national space, Edensor mentions the unremarkable places of shared, daily activities (work and recreation, shopping and services), streetscapes, and motorscapes, styles of housing, garden ornamentation or home decoration, local flora and fauna - all those recurring, serial features of space that facilitate a sense of homeliness nearly everywhere across the nation. ${ }^{(77)}$ The perception of such spatial elements is not cognitive, but sensual, experiential, and participatory, grounded in bodily dispositions and patterns of use embedded in memory, which engenders an affective sense of place that deepens in time as one grows up and lives in a certain locality. ${ }^{(78)}$ In my research material, this affective bond is emphasised by inscriptions that construct the utterer as a local inhabitant and a national "I": "Taipei, sweet city of mine" and "I love local goods" (Wo ai guohuo 我愛國貨). Photographs and drawings of familiar spaces and numerous objects that populate these spaces are featured as signs of Taiwan. Although some are explicitly anchored in particular localities (the West Central District in Tainan, Songshan railway station, Pingxi, Hengchun Township in Pingdong County, and so on), no specific visual traits mark them out as unique - they are elements and arrangements of space encountered all over the island, especially in urban areas. They are sometimes accompanied by inscriptions that emphasise their generic and national character: "Taiwan's night markets" (Taiwan yeshi 台灣夜市), "Taxis in Taiwan," "Scooters on the streets" (with the "Taiwan" logo next to the inscription).

The spaces pictured in the analysed texts are examples of a mundane, vernacular aesthetics, radically different from the conventionalised images of urban modernity usually depicted on postcards. Some of them are simply commonplace: street views with high-rise office buildings covered in mirror tiles, vertical shop signs, traffic lights and signs, and busy traffic (buses, cars, yellow cabs, blue mini-trucks, scooters), a small, local Earth God temple, night market scenes, and betel nut stands with star-shaped rotating neon signs outside. Other landscapes, however, are rather the opposite of quality, orderly urban design. On a set of glass coasters designed by 6636 Advertising \& Creativity, there are bird's eye views of chaotically-built apartment blocks of various sizes crowded into each other, with water tanks, TV aerials, illegal extensions, gardens, and pigeon cages on top, iron bars in the windows, air conditioners hanging outside, laundry hung out to dry, and odd objects stored on balconies. A series of postcards by Renren Publishing Co. Ltd. portrays cats in Anping on street views with tangled electric cables and low, dilapidated buildings, plaster peeling off walls, exposing the bricks underneath. The Taiwaneseness of certain landscapes is already estab-

70. The railways are also promoted by tourist souvenirs depicting the Japanese colonial period and the martial law era; as they do not refer to contemporary Taiwan, these items are not discussed in the present paper. Many such souvenirs are designed by a manufacturer that specifically focuses on the island's railway culture: the Taiwan Railway Company (http://www.tr.net.tw/about.asp, accessed on 23 March 2015).

71. Guo-Juin Hong, Taiwan Cinema: A Contested Nation on Screen, op. cit., pp. 46-47, 54, 57-58, 122.

72. Benedict Anderson, Imagined Communities, op. cit., pp. 22-36.

73. The frequency of railway motifs on the tourist souvenir market suggests the actual existence of such a niche tourist trend or community of interest in Taiwan, a fact confirmed by the official media (such as the Taiwan Info website run by the Ministry of Foreign Affairs; http://taiwaninfo.nat.gov.tw/ct.asp? xltem=92073\&CtNode=124\&htx_TRCategory=\&mp=4, accessed on 13 August 2015). Both the article quoted above and other sources (such as the Tourism Bureau under the Ministry of Transportation and Communications) depict Taiwan's railroad system as part of the national heritage (http://eng.taiwan.net.tw/m1.aspx?sNo=0002039; accessed on 13 August 2015).

74. John Urry and Jonas Larsen, The Tourist Gaze 3.0, op. cit., pp. 12-17

75. Ibid., pp. 16, 98-99, 124.

76. Tim Edensor, National Identity, Popular Culture and Everyday Life, op. cit., p. 19.

77. Ibid., pp. 50-53.

78. Ibid., pp. 59-60 

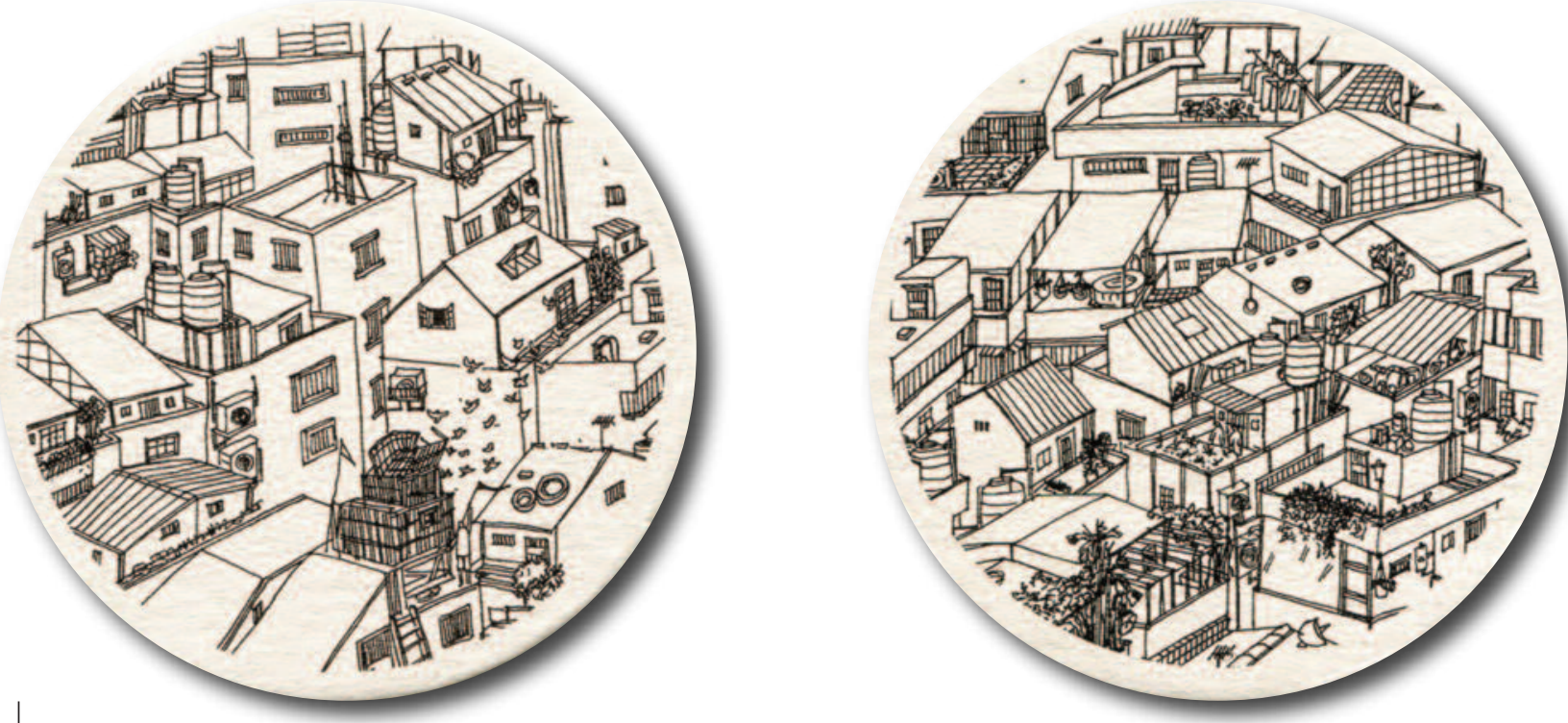

Illustration 4 - Urban vernacular architecture - mundaneness as an extraordinary spectacle. Set of beverage coasters. (๑) 6636 Advertising \& Creativity.

lished: "betel nut beauties" in their glass booths (the topic of a Miin Design postcard) figure in both Western and Taiwanese media as a trademark feature of the island, and night markets (another postcard from the same series) are mentioned in most tourist guides. Apartment blocks of the kind described above may be less of a local brand, but their Taiwanese specificity has been remarked. Zhu Tianwen's short story "Fin de Siècle Splendor," for instance, speaks of "roofs [...] covered with illegal structures built with corrugated iron," describes this architectural style as typically Taiwanese ("different from the West and again different from Japan"), and attributes its lightweight character to the local climate. ${ }^{(79)}$

Apart from whole street scenes, some of which already function as signs of Taiwan, many individual objects recurrent as serial features of quotidian landscapes are also promoted as national trademarks in my research material: buses, yellow cabs, scooters, name seal and bubble tea shop signs, pawnshop signs, outdoor signs for foot massage parlours, dentists, opticians, HeySong ads, alcohol and tobacco retailer signs issued by the Taiwan Tobacco and Liquor Corporation (still hanging on the streets in some places), and objects present in many Taiwanese homes, such as the Datong rice cooker. These elements do not occur within the everyday cityscapes mentioned above (as do buses, small blue lorries, and cabs in the background of a Miin Design postcard focusing on scooters), but instead are singled out as sole topics of postcards or stickers. For instance, a postcard by Milu Design is exclusively dedicated to the yellow cab: it is made of hard cardboard cut in the shape of a cab, with an inscription on the reverse side that points out the characteristic features in the looks of Taiwanese taxis (the yellow chassis, the taxi sign above, written in red lettering against a white background); one sticker out of a set by Qingtian Paper Gifts Ltd. has the same topic. Miin Design's offer also includes a set of bookmarks depicting various kinds of Taiwanese shop signs. The fact that such elements are cut out of the background and presented individually as markers of Taiwaneseness hammers home the de-naturalisation to which they are submitted in the process.

All these representations of everyday landscapes turn mundaneness (and even ugliness) into an extraordinary spectacle (in Urry and Larsen's terms), and make up an image of Taiwan that contrasts with the refinement of classical Chinese culture promoted in the state discourse of public diplomacy and the nationally neutral familiarity of the "Heart of Asia" logo. The unpretentious character of this image and the emotional attachment to such homely spaces are sometimes directly formulated: the description on the back side of the Miin Design shop sign bookmark set mentions "kindly vulgar symbols" (Qinqie de lisu xianghui 親切的㘿俗象徽), and a Qingtian Paper Cift Ltd. sticker set labels several items (such as the scooter) as "for use exclusively by taike" (taike zhuanyong 台客專用), a concept that connotes a lowly subculture hinted at by both items; the connection is also made at the visual level, through objects and stylistic conventions usually promoted as taike aesthetics. ${ }^{\left({ }^{80}\right)}$ The sticker set also engages in a tongue-in-cheek dialogue with the China-centred project of nationhood based upon a millennium-old high culture, and subverts it through appropriating its form: the characters for taike zhuanyong are written in red and placed inside a square frame, which makes them look like a traditional or official seal. The same strategy is to be found on a postcard by Ideapen Design, which displays the two characters for taike merged into one, written in black calligraphy against a red background. Calligraphy and the red colour may connote traditional Chinese culture, but the concept of taike itself is brought back to Taiwan: a goldcoloured map of the island is enclosed into the lower part of the character for ke. The map is embossed, and thus also visible on the postcard's reverse side, where it occurs alone, without any elements that would link it to China.

\section{Places and objects with stories to tell: Constructing a national heritage}

In Anderson's account, the national community is imagined as a unique entity not only across space, but also in time, with its own past and future destiny; constructing the nation also implies writing a national history. ${ }^{(81)}$

79. Tianwen Zhu, "Fin de Siècle Splendor," transl. by Eva Hung, in Joseph Lau and Howard Goldblatt (eds), The Columbia Anthology of Modern Chinese Literature, New York, Columbia University Press, pp. 444-445.

80. See Xian Yiying, Call Me Taike!, Taipei, Wanglu yu shu, 2005, pp. 12-29, 54 
This history is not written once and for all; as Billig states, "Nations often do not typically have a single history, but there are competing tales to be told. [...] Different factions, whether classes, religions, regions, genders or ethnicities, always struggle for the power to speak for the nation [...] national histories are continuously being re-written, and the re-writing reflects current balances of hegemony." (82) During martial law, national history in Taiwan was that of China. Within a general trend towards de-sinification and Taiwanisation, the 1980s ushered in a process of rewriting national history. ${ }^{(83)}$ This preoccupation was noticeable in the political, academic, and educational spheres, but was also reflected in popular culture (such as the New Taiwan Cinema). The tourist souvenirs analysed here join in the struggle over the articulation of national history, alongside those voices that uphold the reconstruction of historical continuity - the need to restore historical chapters erased by previous political regimes within the national narrative and to re-establish links between them. ${ }^{(84)}$

Edensor mentions how ideologically loaded, emblematic sites that "constitute ceremonial points of reference" function as evidence of the past (commemorate important events in national history), or celebrate the nation's modernity and progress. ${ }^{\left({ }^{85}\right)}$ On the other hand, many theories of the nation overemphasise its past and future advancement, while neglecting the present, "the everyday, which is [...] equally important in establishing a sense of national identity." (86) The tourist souvenirs I analyse feature both kinds of places - emblematic sites and quotidian landscapes, allotting even more space to the latter than to the former. However, it is not only the former kind that connotes the past (or the future), but the latter as well. The presence of less famous sites and the de-naturalisation of mundane spaces and objects may surprise the viewer, make him/her wonder why they are singled out, inquire into various details related to these objects, and discover their stories, woven into the canvas of Taiwan's history. Thus my research material encourages what Urry and Larsen call an "anthropological gaze," which interprets sights and sites "within a historical array of meanings and symbols." (87)

Therefore, these tourist souvenirs not only have the potential to encode individual place-related experiences, ${ }^{(88)}$ but are also repositories and activators of collective memories - they formulate a national heritage in which every period in Taiwan's past has its place. The objects visually depicted in my research material thus become monuments, ${ }^{(89)}$ or lieux de mémoire in Pierre Nora's term ${ }^{(90)}$ - they commemorate various chapters in Taiwan's history and contribute to making a national ideology ${ }^{(91)}$ by connoting each period's formative effects for contemporary Taiwan.

The Tainan Confucius Temple was built in 1665 under the rule of Zheng Jing, Koxinga's son; its image not only relates to Confucianism, whose influence is still detectable in contemporary Taiwanese society, but also commemorates the Ming loyalist story and connotes its subsequent interpretations, such as the parallel between Koxinga and Chiang Kai-shek in their fight conducted from bases on Taiwan against mainland regimes perceived as illegitimate, a parallel that was played upon in Chiang's personality cult. ${ }^{(92)}$ Other sites are related to the Japanese colonial period and the modernisation project implemented during that era: the Longteng Bridge dates back to 1906, the Xinzhu train station to 1913 , and the Pingxi railway line was completed in 1921 to serve coal mining. The Datong rice cooker, mass produced since 1960, ushered in a "kitchen revolution" of electric appliances and symbolises Taiwan's economic miracle; taxis and scooters were introduced in the same decade. The Sun Yat-sen Memorial Hall, the Chiang Kaishek Memorial Hall, and the Ci'en Pagoda at Sun Moon Lake were built in

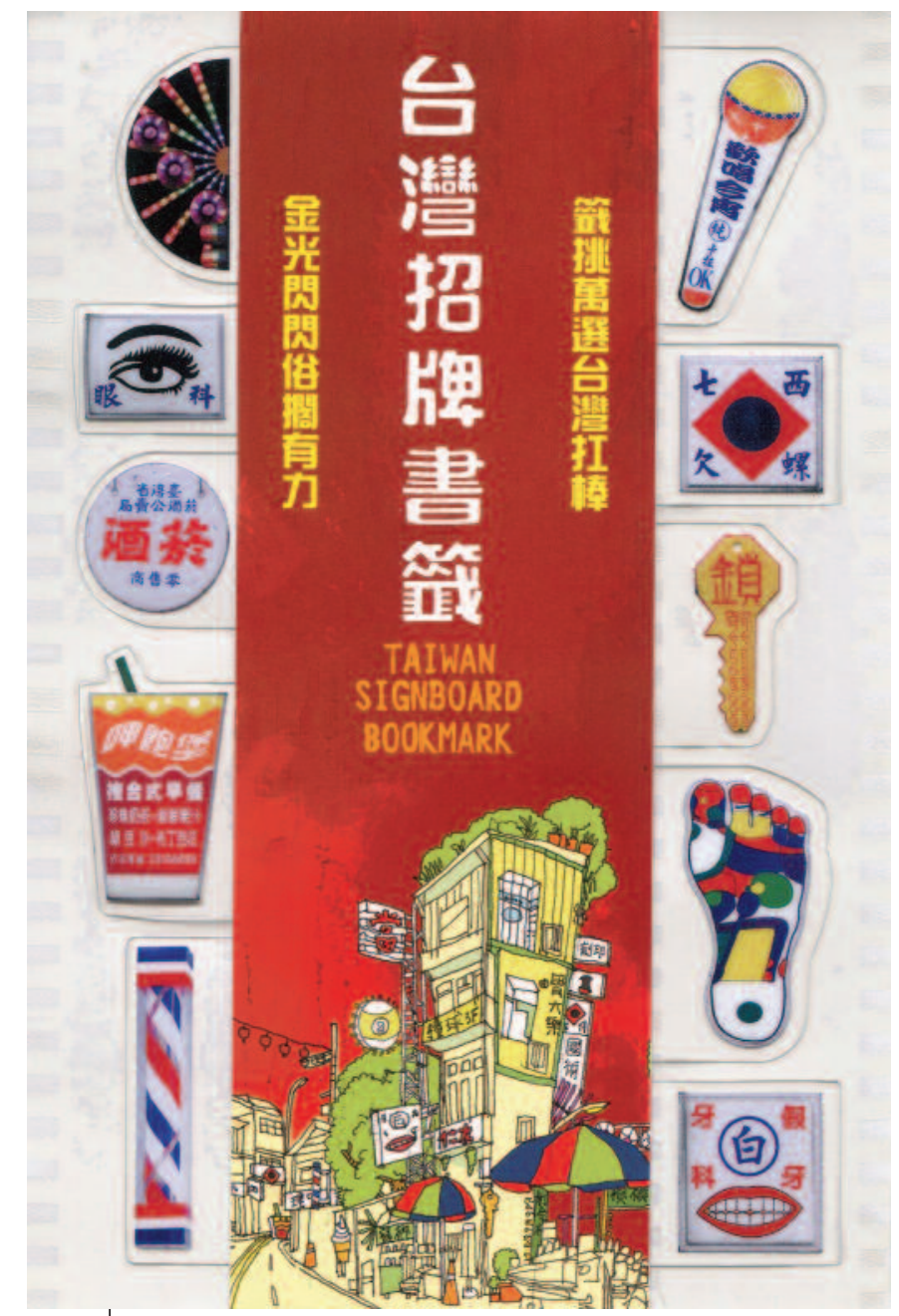

Illustration 5 - "Kindly vulgar symbols." Shop sign bookmarks. ๑ Miin Design Co., LTD.

the 1970s; they embody the China-centred national identity promoted during the martial law period and connote the Confucian values upheld by the KMT and Chiang himself since the Nanjing era (such as filial piety - Chiang commissioned the Ci'en Pagoda as a tribute to his mother). The MRT Jiantan

81. Benedict Anderson, Imagined Communities, op. cit., pp. 11-12.

82. Michael Billig, Banal Nationalism, op. cit., p. 71.

83. Bi-yu Chang, "From Taiwanisation to De-sinification. Culture Construction in Taiwan Since the 1990s," art. cit;; Fu-chang Wang, "Why Bother About School Textbooks? ...," art. cit.

84. The idea of bringing out hitherto missing pieces in order to restore continuity in Taiwan's history reflects a broader concern, which emerged with the DPP's rise to power and is still present in the political discourse and in popular culture. Among the most recent examples are an electoral speech by Taipei mayor Ko Wen-je (2 March 2014; https://www.youtube.com/watch?v= 3xz607Q22wM\&feature=youtu.be, accessed on 27 March 2015), and writer Yang Cui's preface to Lin Lijing's comic book, My Youth, My Formosa, Taipei, Wuxian, 2012.

85. Tim Edensor, National Identity, Popular Culture and Everyday Life, op. cit., p. 45.

86. Ibid., p. 19

87. John Urry and Jonas Larsen, The Tourist Gaze 3.0, op. cit., p. 20.

88. This aspect, not discussed in my paper, is elaborated upon by Shelley Hornstein, Losing Site: Architecture, Memory and Place, op. cit., pp. 11, 56.

89. Ibid., p. 59.

90. Pierre Nora, "General Introduction: Between Memory and History," in Pierre Nora (ed.), Realms of Memory. Rethinking the French Past, Vol. I, Conflicts and Divisions, transl. by Arthur Goldhammer, New York, Columbia University Press, 1996, pp. 1-20.

91. Shelley Hornstein, Losing Site: Architecture, Memory and Place, op. cit., p. 59.

92. Jeremy E. Taylor, "The Production of the Chiang Kai-shek Personality Cult, 1929-1975," The China Quarterly, Vol. 185, 2010, p. 104. 


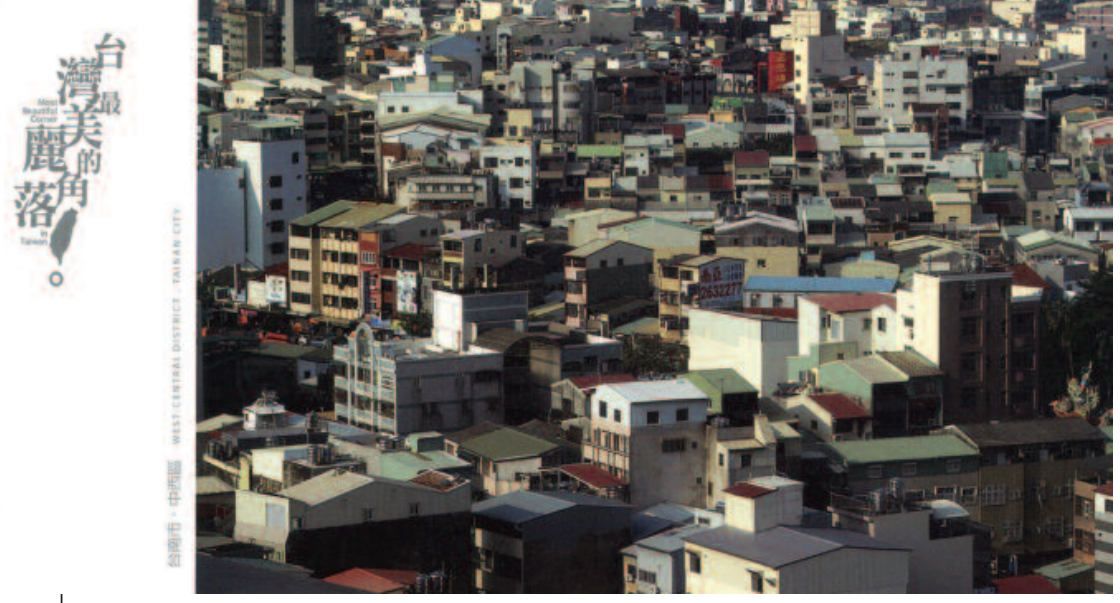

Illustration 6 - "Community of fate" on historical grounds - contemporary view of an area earliest settled by Han Chinese. Postcard. $\odot$ Frogfree.

station, a prize-winning architectural project incorporating elements of the traditional Chinese dragon boat, was built in 1997. Taipei 101 (2004) is an iconic site in Xinyi District, a new alternative downtown area that emerged in the 1990s and the site of the new City Hall since 1994, when Chen Shuibian became mayor. The EcoARK pavilion was built in 2010 out of recycled PET bottles and exemplifies modern, sustainable architecture. The two latter sites stand for global modernity, political transformation, and values that represent Taiwan's commitment to the future.

Some of the featured sites are historical palimpsests, and thus tell multilayered stories of reinterpretation (93) and displacement. ${ }^{(94)}$ Fort San Domingo was built by the Spanish in 1629 and later destroyed; its present structure was erected in 1644 by the Dutch. In 1683 it was taken over by the Qing, and from 1868 onward it served as the British consulate until it was reclaimed by the ROC government in 1980. The Ximending Red House in Taipei was built in 1908 by the Japanese as the entrance to a public market; it was used as a theatre and cinema after 1945, and now hosts representatives of the creative industries. The Dajia River Bridge was initially a railway bridge completed in 1908; the tracks were dismantled in 2004, and the bridge is now part of the Hou-Feng Bikeway. The Presidential Office Building in Taipei, featured on a sticker with the inscription "the state president is at work" (zongtong shangban 總統上班), which emphatically locates state power on the island, is also a symbol of displacement of the Japanese colonial government by the KMT authorities in 1949. The Yuanshan Grand Hotel is the acme of Nationalist nostalgia for Chinese architecture, erected on the original grounds of the Taiwan Grand Shinto Shrine. The Taipei Fine Arts Museum, opened in 1983, stands on the former site of the US Taiwan Defense Command. But perhaps the most interesting story in terms of the approach to national history in my research material is told by the postcard showing a bird's-eye view of the present-day West Central District in Tainan. This area has the longest history of Han Chinese settlement in Taiwan, and many heritage sites from various historical periods are clustered there. However, what the postcard shows is not conventional tourist attractions, but a rooftop view of an ordinary residential area in all its mundaneness. Such a representation of the West Central District summons the same message about Taiwan that is conveyed throughout my research material. The definition of Taiwan is grounded in a present standpoint: Taiwan is the present result of local geographical conditions and (to a greater extent) of various historical experiences (including historical ruptures) and cultural influences that occurred in different periods. The national community thus imagined (the Tainan postcard emphasises the idea of a closeknit "community of fate") may be described as postmodern, as it draws its present specificity not from any single, autochthonous tradition, but from acknowledging all those diverse identities and manifold outside influences whose combination has formed a unique entity.

\section{Conclusions}

The nation-branding project in the tourist souvenirs analysed above is undertaken by grassroots agents - private souvenir manufacturers who explicitly declare involvement in the national cause and undertake convergent efforts at constructing a national imagery that seems to draw inspiration from official sources, but also to distance itself from them by formulating a discourse of Taiwaneseness that is complex, coherent, and firmly anchored in local soil. These grassroots contributions to branding the nation are engaging in a self-reflexive dialogue with existing theories of nationhood and most recent global trends in nation-branding and heritage-making. The branding of "Britishness" through everyday, local, and domestic objects, spaces, and soundscapes is examined by Edensor in his chapter on the Millennium Dome. ${ }^{(95)}$ The diversification and worldwide proliferation of heritage sites as well as local, grassroots British initiatives related to preserving and exhibiting vestiges of non-elite cultures, social experiences, and ordinary working spaces is discussed by Urry and Larsen. ${ }^{(96)}$ Interestingly, Taiwanese souvenir designers echo a logo also designed in Britain - the Tourism Bureau's 2011 "Taiwan - The Heart of Asia," authored by the UK-based company Winkreative.

Like the official slogan, the items in my sample highlight Taiwan's name; however, instead of a neutral heart shape, the nation's name is accompanied by logo-like representations of the national territory and by the national flag. Despite striking stylistic resemblances to the "Heart of Asia" logo that some of the analysed souvenirs ${ }^{(97)}$ display, they depict much more numerous tourist sites from all over the island, on and off the beaten track. Notwithstanding their graphic style, the items in my sample also reflect the everyday character of certain elements in the heart logo ${ }^{(98)}$ but significantly develop this motif by de-familiarising the mundane and unsightly, constructing them as pleasurable and extraordinary and offering them to the viewer as objects of the tourist gaze. This vernacular aesthetics provides coherence to the constructed national imagery, constitutes an alternative towards the officially promoted high (Chinese) culture, and (together with representations of the railway network) conveys a sense of nationwide community. The foregrounding of everyday sights and less famous tourist sites also potentially mobilises viewers towards discovering stories and cultural meanings that lie behind objects, thus encouraging an anthropological gaze. The historical connotations of objects and sites construct a multi-layered

\footnotetext{
93. Tim Edensor, National Identity, Popular Culture and Everyday Life, op. cit., pp. 47-48.

94. Joseph R. Allen, Taipei: City of Displacements, op. cit., p. 188.

95. Tim Edensor, National Identity, Popular Culture and Everyday Life, op. cit., pp. 171-189.

96. John Urry and Jonas Larsen, The Tourist Gaze 3.0, op. cit., pp. 136-146.

97. The postcards issued by Miin Design and Milu Design, and the Qingtian sticker sets.

98. Such as the two people eating at the table, or the chopsticks and steamed buns at the very bot-
} tom. 
national heritage, more complex and localised than the one accounted for by artefacts such as the already mentioned Ministry of Foreign Affairs diary pad. Apart from the high visibility it imparts to Taiwan, the motif of the lowly and mundane may become the basis for a "cultural geometry" (99) in local design.

The grassroots project discussed in this paper may engage with a brand logo designed outside Taiwan, but it also reflects and carries on local discourses and policies. It may stem from the Democratic Progressive Party (DPP) government's emphasis on the creative industries (instead of KMT's high culture) and on boosting domestic tourism. ${ }^{(100)}$ The notable preoccupation with the ordinary and the everyday may echo the late 1970s "back to xiangtu" (鄉土) trend, which turned intellectuals' attention toward the plight of the lower classes and fuelled social activism. ${ }^{(101)} \mathrm{A}$ negative stereotype of the taike associated with the Native Taiwanese ethnic group was formulated by the post-World War II Mainlander government, was taken up by advocates of localisation in the early 1990s, reached its heyday during Chen Shui-bian's presidency as an ethnically-marked subculture used to promote Taiwaneseness, ${ }^{(102)}$ and is still present in contemporary popular culture. ${ }^{(103)}$ My sample refrains from radical political statements: it does not contest the nation's representation by the ROC government and thus seems to uphold the "one China" principle. However, it distances itself from the 1992 Consensus by using the word "Taiwan" to name the nation and emphatically delineating a national territory limited to the island itself.

One may suspect, therefore, that my research material is just as ideologically marked as the official soft power programme discussed by Rawnsley ${ }^{(104)}$ and simply reiterates ideas dominant while the DPP was in power, which at the time of my research made a comeback from below as part of an oppositional discourse outside the political mainstream ${ }^{(105)}$ and the overly commercialised mainstream media that emerged in the context of public anxiety over re-sinification during Ma Ying-jeou's presidency ${ }^{(106)}$ and over the perceived threat from China. A closer look, however, reveals that these texts do not aim at taking antagonising political or ethnic sides, but instead reflect a preoccupation with articulating and promoting Taiwan's subjectivity ${ }^{(107)}$ in forms with broader appeal. They embrace the lowliness connoted by the taike stereotype, but dismantle its connection with the Hoklo and extend it to the built environment and everyday objects present throughout the island. They highlight not only the Japanese colonial past, but other chapters in history as well, including Chiang Kai-shek's rule and the China-centred identity still present in Taiwan today. The assessment of the post-war KMT rule in my research material does not resemble the DPP policy of "de-Chiang-Kai-shek-ification" (qujianghua 去蔣化) pursued after its advent to power ${ }^{(108)}$ - the KMT-related chapter in Taiwan's history is not rejected, but rather incorporated into the national narrative. Taiwan's Chinese connections are neither denied nor excessively emphasised - they are simply listed among the array of cultural influences and identities that shaped Taiwan as a complex whole. The non-antagonistic, all-embracing character of Taiwan's definition as constructed by the analysed souvenirs is different from the China/Taiwan ambiguity in the official discourse. It may be due only to the need to please the public inherent in commercial, popular culture, but it may also stem from a need to shift the focus to national rather than international consensus. It may respond to recent changes in the articulation of national identity consisting of an increase in local identification notwithstanding ethnicity and political options, especially from the younger generations, for whom old ethnic distinctions are no longer as clear-cut and relevant as in the past. Instead of a diplomatically safe message based on Chinese heritage or generic, neutral images of Taiwan, and which reinforces existing tourist preferences, my research sample interpellates an entire Taiwanese "community of fate" and formulates a message of island-centred, island-wide, and palpable locality through everyday sights that can readily engage both a Taiwanese and an international audience.

Idina Zemanek is Assistant Professor at the Institute of the Middle and Far East, Jagiellonian University.

Jagiellonian University, Gronostajowa 3, 30-387 Krakow, Poland

(adina.zemanek@uj.edu.pl).

Manuscript received on 30 May 2016. Accepted on 20 December 2016.

99. Keith M. Murphy, "A Cultural Geometry: Designing Political Things in Sweden," American Ethnologist, Vol. 40, No. 1, 2013, pp. 118-131.

100. Bi-yu Chang, "From Taiwanisation to De-sinification: Culture Construction in Taiwan Since the 1990s," China Perspectives, Vol. 56, p. 6.

101. A-chin Hsiau, Contemporary Taiwanese Cultural Nationalism, op. cit., p. 68.

102. Xian Yiying, Call Me Taike!, op. cit.

103. Recent examples are Niu Chengze's film Monga (2010) and Zhongguo Shibao, Taiwan guanjianzi: shi'er ge shehui xin dongli (Taiwan key words: Twelve new social motive forces), Taipei, Tianxia wenhua, 2013.

104. Gary Rawnsley, "Taiwan's Soft Power and Public Diplomacy," art. cit.

105. The image of a political mainstream shaped by state education promoting a China-centred idea of nationhood, and the necessity for grassroots efforts towards Taiwanisation, are present in historian Zhou Wanyao's preface to Lin Lijing's already mentioned comic book, Lin Lijing, My Youth, My Formosa, op. cit., 2012.

106. A-chin Hsiau, Chonggou Taiwan: dangdai minzuzhuyi de wenhua zhengzhi, op. cit., pp. 6-10.

107. On this topic, see Daniel C. Lynch, "Taiwan's Self-Conscious Nation-Building Project," art. cit.

108. See Jeremy E. Taylor, "The Production of the Chiang Kai-shek Personality Cult, 1929-1975," art. cit. For an earlier stage in this process, see Stéphane Corcuff, "Que reste-t-il de Chiang Kai-shek? Ritualisation d'une commémoration politique à Taiwan (1988-1997)," Études chinoises, Vol 16, No. 2, 1997, pp. 115-146. 